\title{
PENINGKATAN KEMAMPUAN REPRESENTASI MATEMATIS DAN MINAT BELAJAR MATEMATIKA PESERTA DIDIK MELALUI PENDEKATAN REALISTIK BERBASIS BUDAYA MELAYU LANGKAT DI MTS NEGERI TANJUNG PURA KABUPATEN LANGKAT
}

\author{
Khairunnisa \\ Dosen Sekolah Tinggi Agama Islam Jam'iyah Mahmudiyah Tanjung Pura \\ Kabupaten Langkat, Indonesia \\ Email : ayong.nisarao1@gmail.com
}

\begin{abstract}
Abstrak.
Penelitian ini bertujuan untuk: (1) Menganalisis peningkatan kemampuan representasi matematis peserta didik yang diajar melalui pendekatan realistik berbasis budaya Melayu Langkat; (2) Menganalisis peningkatan minat belajar matematika peserta didik yang diajar melalui pendekatan realistik berbasis budaya Melayu Langkat; (3) Menganalisis interaksi antara pembelajaran dengan kemampuan awal matematika (tinggi, sedang, rendah) peserta didik terhadap kemampuan representasi matematis peserta didik; dan (4) Menganalisis interaksi antara pembelajaran dengan kemampuan awal matematika (tinggi, sedang, rendah) peserta didik terhadap minat belajar matematika peserta didik. Penelitian ini merupakan jenis penelitian kuasi eksperimen. Populasi dalam penelitian ini adalah seluruh peserta didik MTs Negeri Tanjung Pura Kabupaten Langkat pada kelas VII yang terdiri dari 7 kelas parallel dan terpilih secara acak dua kelas. Instrumen penelitian yang digunakan terdiri dari tes kemampuan representasi matematis dan angket minat belajar matematika. Instrumen tersebut dinyatakan telah memenuhi syarat validitas isi, serta koefisien reliabilitas sebesar 0,431 dan 0,791 berturut-turut untuk kemampuan representasi matematis dan minat belajar matematika. Analisis data yang digunakan adalah ANAVA dua jalur. Hasil penelitian menunjukkan bahwa (1) Terdapat peningkatan kemampuan representasi matematis peserta didik yang diajar melalui pendekatan realistik berbasis budaya Melayu Langkat; (2) Terdapat peningkatan minat belajar matematika peserta didik yang diajar melalui pendekatan realistik berbasis budaya Melayu Langkat; (3) Tidak terdapat interaksi antara pembelajaran dengan kemampuan awal matematika (tinggi, sedang, rendah) peserta didik terhadap peningkatan kemampuan representasi matematis peserta didik; dan (4) Tidak terdapat interaksi antara pembelajaran dengan kemampuan awal matematika (tinggi, sedang, rendah) peserta didik terhadap peningkatan minat belajar matematika peserta didik.
\end{abstract}

Kata Kunci: Representasi Matematis, Minat Belajar Matematika, Pendekatan Realistik Berbasis Budaya Melayu Langkat, dan Kemampuan Awal Matematika Peserta didik

\begin{abstract}
This research aimed to: (1) Analyze the mathematical representation increased capacity students taught through a realistikistic approach based Langkat Malay culture; (2) Analyze the increased interest in learning mathematics students taught through a realistikistic approach based Langkat Malay culture; (3) Analyze interaction between the learning with prior knowledge of mathematics (high, medium, low) students' abilities to the ability of students mathematical representation; and (4) Analyze interaction between the learning with prior knowledge of mathematics (high, medium, low) students' abilities to the student interest in mathematics learning; as well as the answers to the ability of a mathematical representation of students in each lesson. This study is a quasi-experimental research. The population in this study were all students of MTs Negeri Tanjung Pura Langkat in class VII, comprising 7 parallel classes and randomly selected two classes. The research instrument used consisted of a mathematical representation ability tests and questionnaires interest in learning mathematics. The instrument has been declared eligible content validity, and reliability coefficient of 0.431 and 0.791 respectively for the mathematical representation capability and interest in learning mathematics. The data analysis used was ANOVA two lanes and a descriptive analysis of the answers to math students. The results showed that (1) There has been an increase the ability of students taught mathematical representation through a realistikistic approach based on Malay culture Langkat; (2) There has been an increased interest in learning math students taught through a realistikistic approach based on Malay culture Langkat; (3) There is no interaction between learning approach with prior knowledge of mathematics (high, medium, low) students to increase the ability of students' mathematical representation; and (4) There is no interaction between learning approach with prior knowledge of mathematics (high, medium, low) to increase student interest in mathematics learning;
\end{abstract}

Keywords: Mathematical Representation Ability, Interest in Mathematics Learning, Realistikistic Approach Based on Langkat Malay Culture, and Prior Knowledge of Mathematics Students 


\section{PENDAHULUAN}

Pendidikan merupakan suatu kebutuhan yang amat penting bagi manusia sebagai upaya untuk dapat menggali dan mengembangkan potensi yang dimilikinya agar dapat menjadikan dirinya pribadi yang berkualitas dan berguna dalam kehidupan yang dijalaninya, baik untuk lingkup pribadi, keluarga bahkan masyarakat. Berkembangnya potensi dalam diri merupakan tujuan dari pendidikan sebagaimana yang terdapat dalam undang-undang nomor 20 tahun 2003 tentang Sistem Pendidikan Nasional Bab II pasal 3 bahwa pendidikan bertujuan untuk berkembangnya potensi peserta didik agar menjadi manusia yang beriman dan bertaqwa kepada Tuhan Yang Maha Esa, berakhlak mulia, sehat, berilmu, cakap, kreatif, mandiri dan menjadi warga Negara yang demokratis serta bertanggung jawab.

Perkembangan ilmu pengetahuan dan teknologi pada saat ini juga akan mempengaruhi pendidikan yang akan diberikan oleh pendidik dan diterima oleh peserta didik disebabkan setiap orang dapat memperoleh informasi sesuai yang diinginkannya tanpa dapat dibatasi sejauh mana informasi yang ingin diperoleh akan digunakan atau diterapkan dalam kehidupan sehari-hari. Oleh karena itu, sudah sepatutnya seorang pendidik harus dapat mengakses dan menguasai informasi yang berkembang sesuai dengan perkembangan ilmu pengetahuan dan teknologi.

Salah satu disiplin ilmu pengetahuan yang sangat berperan penting dalam kehidupan masyarakat modern seperti sekarang ini adalah matematika, karena telah diakui bahwa matematika merupakan salah satu mata pelajaran yang dipandang paling penting di sekolah-sekolah dari tingkat dasar, menengah hingga pendidikan tinggi. Akan tetapi mengajar matematika dengan baik merupakan pekerjaan yang masih terasa sulit dilakukan oleh seorang pendidik dikarenakan setiap saat materi pembelajaran yang berkaitan dengan matematika akan terus berkembang dan akan sangat memerlukan penyelesaian terhadap suatu permasalahan yang timbul dalam mempelajari matematika dan diharapkan dapat membantu peserta didik untuk memahami matematika tersebut. Oleh karena itu, untuk mempelajari dan memahami matematika lebih lanjut sangat diperlukan materi pelajaran yang memuat kondisi atau keadaan serta permasalahan yang ditemukan anak dalam kehidupan sehari-hari. Namun, masih terdapat materi pelajaran matematika di sekolah yang masih bersifat formal sehingga matematika yang ditemukan anak dalam kehidupan sehari-hari sangat berbeda dengan apa yang mereka temukan di sekolah, apalagi materi pelajaran yang diberikan oleh pendidik sangat jarang berkaitan dengan nilai budaya lokal atau nilai budaya yang terdapat pada suatu tempat atau daerah tertentu dari peserta didik. Oleh sebab itu, pembelajaran matematika sangat perlu memberikan muatan/ menjembatani antara matematika dalam dunia sehari-hari yang berkonteks pada budaya lokal dengan matematika sekolah sehingga dapat mencapai tujuan dari pembelajaran matematika itu sendiri.

Adapun tujuan pembelajaran matematika untuk semua jenjang pendidikan dasar dan menengah adalah agar peserta didik memiliki kemampuan: (1) Memahami konsep matematika, menjelaskan keterkaitan antarkonsep, dan mengaplikasikan konsep atau algoritma secara luwes, akurat, efisien, dan tepat dalam pemecahan masalah; (2) Menggunakan penalaran pada pola dan sifat, melakukan manipulasi matematika dalam membuat generalisasi, menyusun bukti, atau menjelaskan gagasan dan pernyataan matematika; (3) Memecahkan masalah yang meliputi kemampuan memahami masalah, merancang model matematika, menyelesaikan model, dan menafsirkan solusi yang diperoleh; (4) Mengkomunikasikan gagasan dengan simbol, tabel, diagram, atau media lain untuk memperjelas keadaan atau masalah; dan (5) Memiliki sikap menghargai kegunaan matematika dalam kehidupan, yaitu rasa ingin tahu, perhatian, dan minat dalam mempelajari matematika, serta sikap ulet dan percaya diri dalam pemecahan masalah (Depdiknas, 2006).

Berkaitan dengan tujuan pembelajaran matematika yang tersebut diatas, National Council of Teachers of Mathematics (NCTM) menetapkan lima standar proses untuk matematika di sekolah, yaitu pemecahan masalah (problem solving), penalaran dan bukti (reasoning and proof), komunikasi (communication), koneksi (connections), dan representasi (representations). Hal ini mendukung penelitian yang dilakukan oleh peneliti untuk melihat salah satu kemampuan yang harus dimiliki oleh peserta didik dalam mempelajari matematika yaitu kemampuan representasi. Kemampuan representasi akan menjadi salah satu kemampuan yang sangat diperlukan sebagai bentuk menyatakan ide-ide dalam menyelesaikan permasalahan dalam matematika dalam berbagai cara. Namun, tidak hanya sekedar kemampuan matematis yang akan dituntut dari peserta didik saat mempelajari matematika, masih terdapat hal lain yang sangat perlu dimiliki oleh peserta didik terhadap matematika yaitu sikap (attitude) terhadap pembelajaran matematika tersebut. Salah satu sikap tersebut adalah minat dalam mempelajari matematika.

Minat dalam mempelajari matematika menjadi sikap yang begitu penting untuk dimiliki oleh peserta didik, karena pada kenyataannya minat belajar anak terhadap matematika masih tergolong kurang atau rendah. Hal ini sesuai dengan ungkapan Siagian (2013: 126) bahwa minat belajar anak terhadap 
matematika itu kurang atau rendah dikarenakan anak kurang mengetahui pengertian tentang hakekat dan fungsi matematika itu sendiri. Padahal mempelajari matematika merupakan salah satu jalan untuk menuju kepada pemikiran yang jelas, tepat dan teliti serta menjadi landasan dari semua ilmu pengetahuan yang ada saat ini.

\section{Kemampuan Representasi Matematis}

Kemampuan representasi matematis yang merupakan salah satu standar proses dalam pebelajaran matematika diharapkan dapat dimiliki oleh peserta didik sebagaimana yang telah dikemukakan oleh NCTM dalam Executive Summary about Principles and Standards for School Mathematics yang mengartikan representasi sebagai ungkapan gagasan, ide, pikiran yang dapat diwakili dalam berbagai cara meliputi: gambar, bahan konkrit, tabel, grafik, simbol bilangan dan huruf, tampilan spreadsheet, dan sebagainya. Cara dimana ide-ide matematika tersebut diwakili atau direpresentasikan merupakan suatu landasan atau dasar bagaimana orang memahami dan menggunakan ide-ide tersebut. Termasuk dalam mempelajari matematika, dimana kemampuan representasi dapat menjadikan peserta didik mengemukakan ide-idenya untuk menyelesaikan permasalahan yang diberikan dalam pembelajaran matematika, khususnya permasalahan dalam pembelajaran matematika yang berkaitan dengan budaya lokal atau budaya setempat.

Sejalan dengan pengertian representasi yang diberikan oleh NCTM dalam pembelajaran matematika di sekolah, Sabirin (2014: 33) juga memberikan pengertian bahwa representasi merupakan salah satu kemampuan matematis yang sangat penting bagi peserta didik dan erat kaitannya dengan kemampuan komunikasi dan pemecahan masalah. Untuk dapat menyelesaikan permasalahan/persoalan dalam matematika, seseorang perlu mengkomunikasikan gagasan/ide-idenya (melakukan representasi) ke dalam bentuk gambar, tabel, grafik, diagram, maupun bentuk representasi lainnya. Dengan representasi, masalah yang semula terlihat sulit dan rumit dapat dilihat dengan lebih mudah dan sederhana, sehingga masalah yang disajikan dapat dipecahkan dengan lebih mudah. Representasi juga berguna sebagai sarana mengkomunikasikan gagasan atau ide matematik peserta didik kepada peserta didik lain maupun kepada pendidik. Pembelajaran matematika di kelas sebaiknya memberikan kesempatan yang cukup bagi peserta didik untuk melatih dan mengembangkan kemampuan representasi matematis.

Pentingnya kemampuan representasi matematis juga dapat dilihat dari standar proses untuk matematika di sekolah yang ditetapkan oleh NCTM dalam Executive Summary Principles and Standards for Mathematics. NCTM menetapkan bahwa program pembelajaran dari pra-taman kanak-kanak sampai kelas 12 harus memungkinkan peserta didik untuk: (1) Menciptakan dan menggunakan representasi untuk mengorganisir, mencatat, dan mengkomunikasikan ide-ide matematis; (2) Memilih, menerapkan, dan menerjemahkan representasi matematis untuk memecahkan masalah; dan (3) Menggunakan representasi untuk memodelkan dan menginterpretasikan fenomena fisik, sosial, dan fenomena matematis. Dengan demikian, kemampuan representasi matematis diperlukan peserta didik untuk menemukan dan membuat suatu alat atau cara berpikir dalam mengkomunikasikan gagasan matematis dari yang sifatnya abstrak menuju konkret, sehingga lebih mudah untuk dipahami.

Akan tetapi, fakta di lapangan tepatnya di Madrasah Tsanawiyah (MTs) Negeri Tanjung Pura Kabupaten Langkat sesuai dengan hasil wawancara dengan beberapa pendidik matematika di sekolah tersebut bahwa matematika masih saja menjadi mata pelajaran yang sulit dan membingungkan bagi sebagian besar peserta didik bahkan kemampuan yang dimiliki peserta didik dalam pembelajaran matematika khususnya kemampuan representasi matematis peserta didik dapat dikatakan masih tergolong rendah, hal ini diperoleh ketika peneliti melakukan observasi awal dengan memberikan soal matematika materi segiempat yang berkaitan dengan budaya Melayu Langkat. Pada materi pelajaran segiempat tersebut diharapkan peserta didik memiliki kompetensi dasar untuk dapat mengidentifikasi sifat-sifat segiempat dan menghitung keliling dan luas bangun segiempat serta menggunakannya dalam pemecahan masalah. Kompetensi dasar tersebut diharapkan tercapai agar tujuan pembelajaran dari materi pokok segiempat dapat tercapai pula. Namun kenyataannya masih banyak peserta didik yang merasa kesulitan dan bingung ketika diminta untuk menyelesaikan soal matematika yang diberikan tentang materi pokok segiempat. Bahkan pendidik matematika mengungkapkan bahwa belum pernah memberikan materi pelajaran matematika yang berkaitan dengan budaya lokal khususnya budaya Melayu Langkat.

Oleh karena itu, diharapkan peserta didik dapat memiliki kemampuan representasi matematis setelah diberikan pembelajaran yang berkaitan langsung dengan sesuatu yang nyata/ realistik berkaitan dengan budaya Melayu Langkat. Sehingga membuat peserta didik untuk lebih memahami sebuah proses dalam menyelesaikan permalasalahan dalam matematika, tidak langsung mengerjakan secara praktis. Sebagaimana Yudhanegara, dkk (2014: 77) mengungkapkan bahwa pada dasarnya proses representasi melibatkan penerjemahan masalah atau ide ke dalam bentuk baru, yang termasuk di dalam proses representasi tersebut adalah pengubahan diagram atau model fisik ke dalam simbol-simbol atau kata-kata 
serta dapat juga digunakan dalam menterjemahkan atau menganalisis masalah verbal untuk membuat maknanya menjadi lebih jelas.

Pengajaran yang melibatkan representasi juga dapat mengacu pendidik dalam meningkatkan kemampuan mengajar matematika kepada peserta didik. Melalui representasi-representasi yang dihadirkan peserta didik dalam menyelesaikan masalah matematika, maka akan ada proses pengembangan wawasan ilmu yang dimiliki oleh masing-masing peserta didik. Hal ini juga berkaitan dengan yang dinyatakan oleh Yudhanegara, dkk (2014: 78) bahwa representasi-representasi yang dibuat oleh peserta didik akan memberi kesempatan kepada pendidik untuk lebih mengetahui dan mengakses bagaimana peserta didik berfikir tentang matematika.

Berikut merupakan bentuk-bentuk operasional representasi matematis yang digunakan sebagai indikator untuk mengukur kemampuan representasi matematis peserta didik:

Tabel 1. Bentuk-bentuk Operasional Representasi Matematis

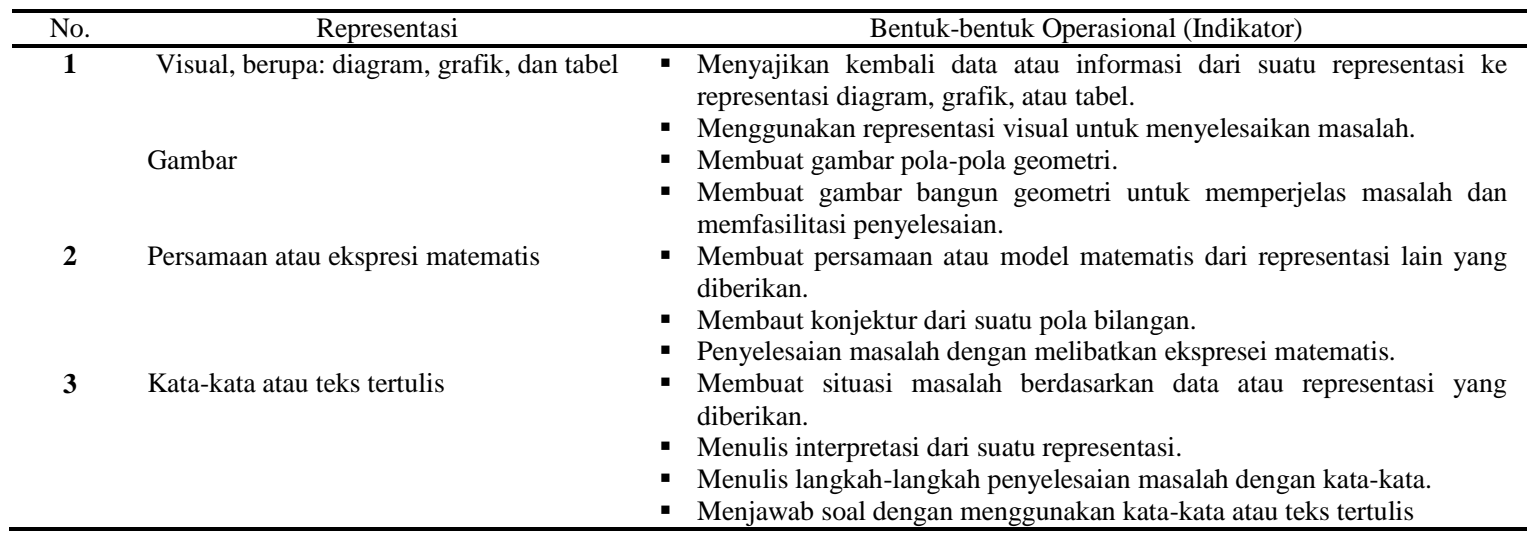

Sumber: Yudhanegara, dkk (2014: 78)

Berdasarkan tabel bentuk-bentuk Operasional atau indikator kemampuan representasi matematis, maka kemampuan representasi matematis yang dimaksud dalam penelitian ini adalah ungkapan gagasan, ide, pikiran peserta didik atas pemahaman dirinya mengenai proses menyelesaian suatu permasalahan matematika dalam bermacam cara sesuai aspek representasi yaitu menyajikan gambar (visual); menuliskan persamaan atau ekspresi matematis; dan menjelaskan dengan kata-kata atau teks tertulis dengan indikator meliputi: (1) Membuat gambar bangun geometri untuk memperjelas masalah dan memfasilitasi penyelesaian; (2) Membuat persamaan atau model matematis dari representasi lain yang diberikan; (3) Penyelesaian masalah dengan melibatkan ekspresi matematis; (4) Membuat situasi masalah berdasarkan data atau representasi yang diberikan; (5) Menulis interpretasi dari suatu representasi; (6) Menuliskan langkah-langkah penyelesaian masalah dengan kata-kata; dan (7) Menjawab soal dengan menggunakan kata-kata atau teks tertulis.

\section{Minat Belajar Matematika}

Selain pentingnya kemampuan representasi matematis dalam pembelajaran matematika bagi peserta didik, hal lain yang dianggap penting adalah sikap peserta didik dalam mempelajari matematika yang salah satunya adalah minat belajar peserta didik. Minat dalam mempelajari matematika juga begitu penting sebagai salah satu sikap menghargai kegunaan matematika dalam kehidupan yang sepatutnya harus dimiliki peserta didik. Oleh karena itu, sudah sepatutnya pendidik dalam melaksanakan pembelajaran matematika dapat memberikan dan membangun konsep-konsep matematika yang dibelajarkan dengan mempertimbangkan aspek-aspek lokal yang berkembang dalam masyarakat di sekitar lingkungan peserta didik, sehingga dapat meningkatkan minat belajar peserta didik dalam mempelajari matematika.

Usman (2010: 27) mengungkapkan bahwa adanya minat peserta didik dalam belajar merupakan salah satu kondisi belajar-mengajar yang efektif, minat dapat dianggap sebagai sifat yang relatif menetap pada diri seseorang dan minat juga berkaitan dengan perhatian peserta didik dalam belajar. Minat tersebut dapat diekpresikan anak didik melalui: (1) Pernyataan lebih menyukai sesuatu daripada yang lainnya; (2) partisipasi aktif dalam suatu kegiatan yang diminati; serta (3) memberikan perhatian yang lebih besar terhadap sesuatu yang diminatinya tanpa menghiraukan yang lain (fokus).

Selanjutnya, beberapa hal yang berkaitan dengan minat diungkapkan Ormrod (2008: 102) dengan menyatakan bahwa peserta didik yang tertarik pada sebuah topik tertentu mencurahkan perhatian yang lebih banyak pada topik itu dan menjadi lebih terlibat secara kognitif di dalamnya. Ormrod juga memaparkan pernyataan yang mengungkapkan bahwa peserta didik yang tertarik pada sebuah topik tertentu cenderung mempelajarinya secara lebih bermakna, terorganisasi, dan terperinci-misalnya, dengan mengaitkannya dengan pengetahuan sebelumnya, membentuk gambar-gambar visual, memberikan 
contoh-contoh, mengaitkan berbagai ide, menarik kesimpulan, serta mengidentifikasi potensi penerapannya. Kemudian, peserta didik yang tertarik pada apa yang mereka pelajari menunjukkan prestasi akademik yang lebih tinggi dan lebih mungkin mengingat materi pelajaran tersebut dalam jangka panjang.

Dalam bidang studi matematika, Siagian (2013: 126) menyatakan bahwa minat seseorang dalam belajar matematika dapat dilihat dari kecenderungan peserta didik untuk memberikan perhatian yang lebih besar terhadap pelajaran matematika tersebut. Sehingga, jika peserta didik tersebut memiliki perhatian besar terhadap pelajaran matematika maka hasil belajar yang akan diperolehnya akan cenderung menuju ke arah yang lebih baik. Hal senada juga dinyatakan oleh Arifin (2011: 241) bahwa berminat tidaknya seseorang terhadap sesuatu dapat dilihat dari beberapa indikator, antara lain perhatian, perasaan, motivasi, dan sikap. Minat dapat diukur dengan teknik observasi, wawancara, inventori, dan sala minat.

Minat belajar matematika yang dimaksud dalam penelitian ini adalah dorongan atau aktivitas mental yang dapat menimbulkan perasaan senang peserta didik terhadap orang (pendidik), benda, kegiatan, pengalaman dalam mempelajari matematika yang dapat dilihat dari indikator perhatian, perasaan, motivasi, dan sikap. Indikator-indikator minat tersebut dituangkan dalam bentuk skala minat yang terdiri atas 20 pernyataan.

Berdasarkan hasil wawancara yang dilakukan peneliti kepada pendidik matematika dan beberapa orang peserta didik, menyimpulkan bahwa minat peserta didik dalam mempelajari matematika cenderung rendah dikarenakan peserta didik hanya berfikir bahwa pelajaran matematika itu penuh dengan rumus dan hitungan tanpa berfikir tentang fungsi dan manfaat belajar matematika itu sendiri dalam kehidupan seharihari. Selain itu, faktor lain yang menyebabkan rendahnya minat peserta didik dalam mempelajari matematika adalah materi pelajaran yang diberikan pendidik masih bersifat formal dan abstrak. Hal ini senada dengan yang diungkapkan Siagian (2013:126) bahwa minat belajar anak terhadap matematika itu kurang atau rendah dikarenakan anak kurang mengetahui pengertian tentang hakekat dan fungsi matematika itu sendiri. Padahal matematika merupakan salah satu jalan untuk menuju pemikiran yang jelas, tepat dan teliti serta melandasi semua ilmu pengetahuan.

Berdasarkan fenomena diatas, sudah seharusnya pendidik mencari suatu cara untuk dapat meningkatkan kemampuan matematis yang dimiliki peserta didik bahkan sikap positif peserta didik dalam mempelajari matematika untuk dapat menghargai kegunaan matematika dalam kehidupan seharihari. Salah satu pembelajaran yang dapat membangun pengetahuan peserta didik, pembelajaran yang berpusat pada peserta didik serta pembelajaran yang dapat meningkatkan kemampuan representasi matematis dan minat belajar matematika peserta didik yaitu dengan menerapkan suatu pendekatan pembelajaran dari Pendidikan Matematika Realistik (RME). Hal ini sesuai dengan pernyataan Wijaya (2012: 28) bahwa:

"Dalam Pendidikan Matematika Realistik, konteks yang digunakan diawal pembelajaran ditujukan untuk titik awal pembangunan konsep matematika dan untuk memberikan kesempatan kepada peserta didik untuk melakukan eksplorasi strategi penyelesaian masalah. Selain bermanfaat untuk mendukung kegiatan eksplorasi, penggunaan konteks di awal pembelajaran juga akan bisa meningkatkan minat dan motivasi peserta didik dalam belajar. Pembelajaran matematika yang langsung dimulai pada tahap matematika formal seringkali menimbulkan kecemasan matematis (mathematical anxiety) bagi peserta didik."

Pernyataan Wijaya tersebut sesuai dengan tujuan pembelajaran matematika dalam kurikulum 2013 yang menekankan pada dimensi pedagogik yang modern dalam pembelajaran, yaitu menggunakan pendekatan ilmiah (scientific approach). Dalam pendekatan ilmiah ini, pembelajaran matematika menjadi lebih bermakna karena diawali dengan kegiatan mengamati, kemudian dilanjutkan dengan kegiatan menanya, mencoba, menalar, menyaji, dan mencipta. Maka dari itu, pada saat kegiatan awal mengamati akan sangat bermakna jika diberikan suatu permasalahan nyata/realistik sesuai dengan kehidupan seharihari.

\section{Pendidikan Matematika Realistik}

Pendidikan Matematika Realistik (PMR) merupakan suatu pendekatan dalam pembelajaran matematika di Belanda yang memiliki konsep utama yaitu kebermaknaan konsep matematika. Hal ini sesuai dengan pendapat Freudhental (dalam Wijaya, 2012: 20) yang menyatakan bahwa proses belajar peserta didik hanya akan terjadi jika pengetahuan (knowledge) yang dipelajari oleh peserta didik akan bermakna bagi peserta didik itu sendiri. Sedangkan Cord menyatakan suatu pengetahuan akan menjadi bermakna bagi peserta didik jika proses pembelajaran dilaksanakan dalam suatu konteks atau pembelajaran menggunakan permasalahan realistik. Menurut Wijaya (2012: 21) penggunaan permasalahan realistik (context problem) dalam PMR memiliki posisi yang jauh berbeda dengan penggunaan permasalahan realistik dalam pendekatan mekanistik. Dalam PMR, permasalahan realistik digunakan sebagai pondasi dalam membangun konsep matematika atau disebut juga sebagai sumber 
untuk pembelajaran sedangkan dalam pendekatan mekanistik permasalahan realistik ditempatkan sebagai bentuk aplikasi suatu konsep matematika yang dijadikan sebagai kesimpulan atau penutup dari proses pembelajaran.

Pendekatan realistik dalam penelitian ini merupakan suatu pembelajaran dengan langkah-langkah yang diawali dengan permasalahan atau pengalaman yang dapat ditemukan dalam kehidupan sehari-hari (nyata) peserta didik sehingga dapat memfasilitasi peserta didik membangun konsep dari pengetahuan informal menjadi matematika formal dengan langkah-langkah pembelajaran meliputi: (1) menyampaikan masalah kontekstual; (2) menjelaskan masalah kontekstual; (3) menyelesaikan masalah kontekstual; (4) membandingkan dan mendiskusikan jawaban; dan (5) menyimpulkan.

Pembelajaran yang diberikan dalam penelitian ini berupa pembelajaran dengan pendekatan realistik berbasis budaya lokal khususnya budaya Melayu Langkat.

\section{Pendekatan Realistik Berbasis Budaya Melayu Langkat}

Pendekatan realistik berbasis budaya Melayu Langkat merupakan salah satu pendekatan dalam pembelajaran yang diharapkan dapat memberikan peningkatan terhadap kemampuan representasi matematis dan minat belajar peserta didik. Pendekatan realistik berbasis budaya Melayu Langkat ini lebih menekankan kepada pembelajaran yang diawali dengan memberikan permasalahan atau pengalaman realistik yang terdapat dalam kehidupan sehari-hari atau dalam bentuk pengetahuan informal berkaitan dengan budaya Melayu Langkat.

Arifin (2014: 30) menyatakan bahwa budaya dan kebudayaan merupakan hasil cipta manusia, dimana dalam perkembangan hidup manusia secara disengaja ataupun tidak disengaja telah melakukan aktivitas didalam memenuhi kebutuhan hidup, yang kesemuanya merupakan peradaban manusia dari zaman ke zaman. Maka melalui budaya dan kebudayaan ini pula manusia terdidik dan memiliki budi dan pekerti yang terjelma pada kepribadiannya. Arifin (2014: 5) juga menyatakan bahwa kebudayaan didalam prakteknya memiliki jenis-jenis diantaranya: (1) Kebudayaan material (material culture) adalah wujud dari kebudayaan yang merupakan benda-benda yang nyata dan konkret merupakan hasil karya cipta manusia seperti rumah, mobil, bangunan-bangunan, tempat ibadah, benda hasil teknologi, dan sebagainya; (2) Kebudayaan non material merupakan wujud kebudayaan yang tidak berupa benda nyata non konkret yang merupakan hasil karya cipta manusia, antara lain ilmu pengetahuan baik teori murni maupun yang telah disusun dan dilaksanakan dalam kehidupan manusia. Hasil rasa manusia, merupakan wujud dalam bentuk nilai-nilai dan bermacam norma dan kaedah dalam mengatur tatanan kehidupan serta mengatur tata interaksi sosial dalam arti luas mencakup keagamaan/kepercayaan, ideologi, kesenian, kebatinan dan semua unsur yang merupakan hasil ekspresi jiwa manusia.

Berdasarkan pernyataan Arifin tersebut, maka yang termasuk ke dalam konteks budaya Melayu Langkat yang diterapkan dalam pembelajaran matematika dalam penelitian pada materi ajar segiempat berupa kebudayaan material (material culture) berupa rumah adat, perlengkapan/peralatan adat, dan ornament-ornamen (hiasan) khas Melayu langkat.

Namun, pada kenyataannya pendekatan realistik berbasis budaya Melayu Langkat ini belum pernah diterapkan dalam pembelajaran matematika disekolah. Padahal pembelajaran matematika dengan menerapkan pendekatan realistik berbasis budaya Melayu Langkat dapat memberikan muatan yang menjembatani antara matematika informal dan matematika formal yakni matematika dalam kehidupan sehari-hari yang berkaitan dengan budaya Melayu Langkat dengan matematika sekolah.

Pendekatan realistik berbasis budaya Melayu Langkat dalam penelitian ini adalah proses mempelajari matematika yang diawali dengan memberikan permasalahan atau persoalan yang berkonteks budaya Melayu Langkat agar peserta didik dapat membangun sendiri pengetahuannya (matematika informal ke formal) sehingga pembelajaran yang dilakukan lebih bermakna serta dapat meningkatkan kemampuan representasi dan minat mempelajari matematika.

Berdasarkan penjelasan yang telah diuraikan, maka yang menjadi tujuan dalam penelitian ini adalah (1) untuk menganalisis peningkatan kemampuan representasi matematis peserta didik yang diajar melalui pendekatan realistik berbasis budaya Melayu Langkat; (2) untuk menganalisis peningkatan minat belajar matematika peserta didik yang diajar melalui pendekatan realistik berbasis budaya Melayu Langkat; (3) untuk menganalisis interaksi antara pembelajaran dengan kemampuan awal matematika (tinggi, sedang, rendah) peserta didik terhadap kemampuan representasi matematis peserta didik; dan (4) untuk menganalisis interaksi antara pembelajaran dengan kemampuan awal matematika (tinggi, sedang, rendah) peserta didik terhadap minat belajar matematika peserta didik. 


\section{METODE}

Jenis penelitian ini dilakukan dengan metode eksperimen semu (quasi eksperiment) dengan pendekatan kuantitatif karena kelas yang digunakan telah terbentuk sebelumnya. Penelitian ini menggunakan dua kelompok subjek penelitian yaitu kelompok eksperimen dan kelompok kontrol. Pendekatan kuantitatif digunakan untuk memperoleh gambaran tentang kemampuan representasi matematis dan minat belajar matematika peserta didik pada materi ajar segiempat.

Rancangan penelitian yang digunakan dalam penelitian ini adalah pretest-posttest control group design. Dalam rancangan ini terdapat dua kelompok peserta didik dimana masing-masing kelompok diberikan pretes untuk mengetahui keadaan awalnya kemudian postes untuk melihat keadaan akhir setelah diberi perlakuan.

Instrumen yang digunakan dalam penelitian ini terdiri atas dua jenis instrumen, yaitu jenis tes dan non tes. Instrumen jenis tes berupa soal berbentuk pilihan berganda dan uraian digunakan sebagai instrumen untuk mengukur kemampuan awal matematika dan kemampuan representasi matematis peserta didik sedangkan instrumen jenis non tes ialah berupa angket untuk mengukur minat belajar matematika peserta didik, dan lembar observasi terkait kemampuan pendidik dalam mengelola pembelajaran.

Teknik analisis data yang digunakan dalam penelitian ini adalah analisis secara inferensial. Data yang dianalisis secara inferensial berupa hasil pretes dan postes kemampuan representasi matematis dan minat belajar matematika peserta didik dengan melalui beberapa tahapan sebagai berikut:

1. Tahap uji prasyarat analisis, meliputi uji normalitas data, uji homogenitas, dan menghitung gain ternormalisasi $(N$-Gain); dan

2. Tahap uji hipotesis statistik menggunakan analisis varians dua jalur dengan taraf signifikansi 0,05 .

\section{PEMBAHASAN dan HASIL}

Pembahasan dilakukan secara deskripsi dan interpretasi berdasarkan hasil penelitian yang diperoleh dengan menguraikan faktor-faktor yang terlibat dalam penelitian ini sebagai berikut:

\section{Faktor Pembelajaran}

Hasil penelitian yang telah dinalisis menunjukkan bahwa pembelajaran melalui pendekatan realistik berbasis budaya Melayu Langkat lebih tinggi secara signifikan dalam meningkatkan kemampuan representasi matematis dan minat belajar matematika peserta didik. Pembelajaran melalui pendekatan realistik berbasis budaya Melayu Langkat merupakan pembelajaran yang memberikan permasalahan realistik berkonteks budaya Melayu Langkat yang digunakan sebagai pondasi dalam membangun konsep matematika atau sumber untuk pembelajaran. Pendekatan realistik memusatkan perhatian pada pengetahuan informal (informal knowledge) dan pengetahuan awal (pre knowledge) yang dimiliki peserta didik dan akan menjadi hal yang sangat mendasar dalam mengembangkan permasalahan yang realistik (Wijaya, 2012: 21). Berdasarkan hasil penelitian serta didukung oleh penelitian yang telah dilakukan Arsaythamby dan Zubainur (2014) yang menunjukkan bahwa kegiatan dalam pembelajaran matematika peserta didik yang diajar dengan menggunakan pendekatan realistik lebih tinggi daripada peserta didik yang diajar menggunakan pendekatan konvensional.

\section{Faktor Kemampuan Awal Matematika (KAM) Peserta didik}

Hasil pengujian hipotesis menunjukkan bahwa kemampuan representasi matematis peserta didik yang memiliki kemampuan awal matematika tinggi lebih baik daripada peserta didik yang memiliki kemampuan awal matematika sedang, dan peserta didik yang memiliki kemampuan awal matematika sedang lebih baik daripada peserta didik yang memiliki kemampuan awal rendah. Begitu juga minat belajar matematika peserta didik yang memiliki kemampuan awal matematika tinggi lebih baik daripada peserta didik yang memiliki kemampuan awal matematika sedang, dan peserta didik yang memiliki kemampuan awal matematika sedang lebih baik daripada peserta didik yang memiliki kemampuan awal rendah. Berdasarkan hasil penilitian dalam pelaksanaan pembelajaran matematika dengan menggunakan dua pendekatan pembelajaran untuk masing-masing kelas eksperimen dan kontrol terlihat bahwa peserta didik yang memiliki kemampuan awal matematika tinggi pada kelas yang diajar melalui pendekatan realistik berbasis budaya Melayu Langkat (PRBBML) memperoleh keuntungan dari perlakuan pembelajaran yang diberikan yaitu kemampuan matematikanya akan semakin tinggi pula, hal tersebut dapat telihat ketika peserta didik tersebut aktif dalam pelaksanaan pembelajaran melalui PRBBML terutama dalam menjawab pertanyaan pendidik maupun teman-temannya, sedangkan peserta didik yang berkemampuan sedang dan rendah mengalami kesulitan dalam pelaksanaan pembelajaran bahkan mengalami kendala dalam memahami dan menyelesaikan masalah yang diberikan. Berdasarkan hasil penelitian dan temuan Saragih (2007) yaitu berdasarkan kemampuan awal matematika (tinggi, sedang, rendah), peserta didik yang berkemampuan sedang dan rendah menunjukkan perbedaan yang signifikan tetapi tidak berbeda bagi peserta didik berkemampuan tinggi. 


\section{Kemampuan Representasi Matematis Peserta didik}

Kemampuan representasi matematis adalah bentuk ungkapan gagasan, ide, pikiran peserta didik terhadap suatu permasalahan matematika, yang dilihat melalui beberapa aspek representasi, yaitu menyajikan gambar (visual), menuliskan ekspresi matematik, dan menjelaskan dengan kata-kata (verbal). Berdasarkan hasil analisis data terhadap rata-rata skor pretes dan postes kemudian dihitung untuk peningkatan ( $N$-Gain) kedua kelas, kelas yang diberi pendekatan realistik berbasis budaya Melayu Langat memperoleh rerata skor $\mathrm{N}$-Gain kemampuan representasi matematis yang lebih tinggi daripada kelas yang diberi pembelajaran biasa. Berdasarkan hasil penelitian dan temuan yang telah dilakukan Sabirin (2014:43) bahwa kemampuan representasi merupakan kemampuan yang sangat penting bagi peserta didik dan merupakan salah satu tujuan yang hendak dicapai dalam pembelajaran matematika di Sekolah. Representasi sangat berguna dalam membantu peserta didik menyelesaikan masalah dengan lebih mudah. Sehingga, pembelajaran matematika di kelas sebaiknya memberi kesempatan yang cukup bagi peserta didik untuk melatih dan mengembangkan kemampuan representasi matematis.

\section{Minat Belajar Matematika Peserta didik}

Minat belajar matematika adalah dorongan atau aktivitas mental yang dapat menimbulkan perasaan senang peserta didik terhadap orang (pendidik), benda, kegiatan, pengalaman dalam mempelajari matematika yang dapat dilihat dari indikator perhatian, perasaan, motivasi, dan sikap. Berdasarkan hasil analisis data terhadap rata-rata skor pretes dan postes kemudian dihitung untuk peningkatan $(N$-Gain $)$ kedua kelas, kelas yang diajar melalui pendekatan realistik berbasis budaya Melayu Langkat memperoleh rerata skor $\mathrm{N}$-Gain minat belajar matematika yang lebih tinggi daripada kelas yang diajar melalui pembelajaran biasa. Berdasarkan hasil penelitian dan didukung oleh penelitian yang telah dilakukan Saragih (2007), yang menyatakan bahwa secara keseluruhan peserta didik yang pembelajarannya dengan pendekatan realistik secara signifikan lebih baik dalam meningkatkan sikap positif peserta didik terhadap matematika dibandingkan peserta didik yang pembelajarannya dengan pembelajaran biasa. Penelitian lain yang senada adalah penelitian yang telah dilakukan Aritonang (2008) yang menyatakan tentang minat dan motivasi belajar yang begitu penting dalam menentukan hasil belajar. Terdapat beberapa faktor yang mempengaruhi minat dan motivasi belajar peserta didik yaitu cara mengajar pendidik, karakter pendidik, suasana kelas tenang dan nyaman, dan fasilitas yang digunakan.

\section{Interaksi Antara Pembelajaran dengan Kemampuan Awal Matematika (Tinggi, Sedang, Rendah) Peserta didik terhadap Kemampuan Representasi Matematis dan Minat Belajar Matematika Peserta didik}

Dari hasil analisis perhitungan yang dilakukan terhadap pembelajaran dengan kemampuan awal matematika (tinggi, sedang, dan rendah) peserta didik terhadap peningkatan kemampuan representasi matematis dan minat belajar matematika peserta didik mengindikasikan bahwa tidak terdapat interaksi. Artinya selisih rata-rata tes kemampuan representasi matematis antar peserta didik kategori tinggi, sedang, dan rendah yang diajar melalui pendekatan realistik berbasis budaya Melayu Langkat dengan peserta didik yang diajar melalui pembelajaran biasa tidak berbeda secara signifikan. Hal ini juga menunjukkan bahwa pembelajaran mempunyai pengaruh terhadap kemampuan representasi matematis peserta didik, sedangkan jika dihubungkan dengan kemampuan awal matematika tidak mempengaruhi kemampuan representasi matematis peserta didik. Berdasarkan hasil penelitian dan didukung oleh penelitian yang telah dilakukan Saragih (2007) dengan hasil bahwa tidak terdapat interaksi antara faktor pembelajaran dengan faktor kemampuan awal matematika peserta didik terhadap peningkatan kemampuan berfikir logis, kemampuan komunikasi matematik, dan sikap positif terhadap matematika. Hal ini juga senada dengan penelitian Darma, dkk (2013) dengan hasil bahwa tidak terdapat interaksi pendekatan pembelajaran dan kompetensi awal terhadap pemahaman konsep dan daya matematika peserta didik.

\section{HASIL}

Hasil penelitian yang diuraikan meliputi hasil pretes dan postes yang telah dilakukan peserta didik terkait tes kemampuan representasi matematis dan angket skala minat belajar matematika peserta didik yang diberikan pada masing-masing kelas pembelajaran, yaitu kelas eksperimen yang diajar melalui pendekatan realistik berbasis budaya Melayu Langkat dan kelas kontrol yang diajar melalui pembelajaran biasa.

\section{Deskripsi Kemampuan Awal Matematika (KAM) Peserta didik}

Untuk memperoleh gambaran KAM peserta didik dilakukan perhitungan rerata dan simpangan baku. Hasil rangkuman disajikan pada tabel 2 berikut: 
Tabel 2. Deskripsi KAM Berdasarkan Pembelajaran

\begin{tabular}{lllllcc}
\hline Kelas & $\begin{array}{l}\text { Nilai } \\
\text { Ideal }\end{array}$ & $\mathrm{N}$ & $\boldsymbol{X}_{\min }$ & $\boldsymbol{X}_{\max }$ & $\overline{\boldsymbol{X}}$ & $\mathrm{D}$ \\
\hline Eksperimen & 100 & 37 & 25 & 90 & 53,784 & 16,725 \\
Kontrol & 100 & 37 & 25 & 80 & 50,541 & 15,401 \\
Total/Rata-rata & 100 & 74 & 25 & 85 & 52,162 & 16,063 \\
\hline
\end{tabular}

Selanjutnya dilakukan pengujian untuk mengetahui kesetaraan skor KAM kelas sampel penelitian dengan melakukan uji normalitas data menggunakan uji Kolmogorov-Smirnov. Hipotesis yang diuji untuk mengetahui normalitas data KAM adalah:

$H_{0}$ : sampel berasal dari populasi yang berdistribusi normal

$H_{a}$ : sampel berasal dari populasi yang tidak berdistribusi normal

Kriteria pengujian dengan menggunakan uji Kolmogorov-Smirnov yaitu jika nilai signifikansi (sig.) lebih besar dari 0,05 maka $H_{0}$ diterima sedangkan lainnya ditolak. Berikut merupakan hasil perhitungan uji normalitas data KAM peserta didik yang terangkum dalam tabel 3 berikut:

Tabel 3. Hasil Perhitungan Uji Normalitas KAM Peserta didik (SPSS 20)

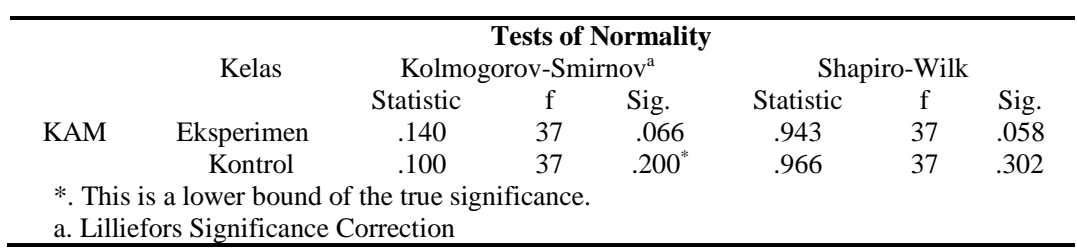

Berdasarkan tabel 3 terlihat bahwa nilai signifikansi berturut-turut adalah 0,066 dan 0,200 untuk kelas eksperimen dan kelas kontrol. Kedua nilai signifikansi tersebut lebih besar dari taraf signifikansi 0,05 maka $\mathrm{H}_{0}$ diterima dan lainnya ditolak. Sehingga $\mathrm{H}_{0}$ yang menyatakan sampel berasal dari populasi yang berdistribusi normal untuk kelas eksperimen dan kelas kontrol dapat diterima.

Karena data pada kedua kelompok berdistribusi normal, amak dilanjutkan dengan melakukan uji homogenitas varians dengan menggunakan uji Levene Statistic. Hipotesis yang diuji untuk mengetahui homogenitas data KAM adalah:

$H_{0}$ : varians dalam tiap kelompok sama

$H_{a}$ : varians dalam tiap kelompok berbeda

Kriteria pengujian dengan menggunakan uji Levene Statistic yaitu jika nilai signifikansi (sig.) lebih besar dari 0,05 maka $H_{0}$ diterima sedangkan lainnya ditolak. Berikut merupakan hasil perhitungan uji homogenitas data KAM peserta didik yang terangkum dalam tabel 4 berikut:

Tabel 4. Hasil Perhitungan Uji Homogenitas KAM Peserta didik

\begin{tabular}{lllllr}
\hline KAM & \multicolumn{5}{c}{ Test of Homogeneity of Variances } \\
Levene Statistic & $\mathrm{df} 1$ & & $\mathrm{df} 2$ & Sig. \\
.298 & & 1 & & 72 & .587 \\
\hline
\end{tabular}

Berdasarkan tabel 4 terlihat bahwa nilai signifikansi sebesar 0,587 yang berarti lebih besar dari taraf signifikansi sebesar 0,05 . Sehingga $\mathrm{H}_{0}$ yang menyatakan varians pada tiap kelompok sama dapat diterima. Selanjutnya dilakukan pengelompokkan KAM peserta didik (tinggi, sedang, rendah) yang didasarkan pada nilai rata-rata $(\bar{X})$ dan standar deviasi (SD) dengan hasil pengelompokkan dirangkum pada tabel 5 berikut:

Tabel 5. Sebaran Sampel Penelitian

\begin{tabular}{lrrr}
\hline \multicolumn{1}{c}{ Kelas Sampel } & \multicolumn{3}{c}{ Kemampuan Peserta didik } \\
\cline { 2 - 4 } Penelitian & Tinggi & Sedang & Rendah \\
Kelas Eksperimen & 9 & 18 & 10 \\
Kelas Kontrol & 9 & 19 & 9 \\
Jumlah & 18 & 37 & 19 \\
\hline
\end{tabular}

\section{Deskripsi Gain Ternormalisasi ( $\mathrm{N}$-Gain) Kemampuan Representasi Matematis}

Berikut merupakan deskripsi $N$-Gain kemampuan representasi matematis peserta didik yang diperoleh dari hasil selisih skor postes dan skor pretes kemudian dibagi dengan selisih skor maksimum dan skor pretes. Hasil $N$-Gain tersebut dirangkum dalam tabel 6: 
Tabel 6. Deskripsi N-Gain Kemampuan Representasi Matematis Kedua Kelompok Pembelajaran untuk Kategori KAM

\begin{tabular}{lccc}
\hline Kategori KAM & Data Statistik & \multicolumn{2}{c}{ Pembelajaran } \\
\cline { 3 - 4 } Tinggi & & PRBBML & PB \\
& $\mathbf{N}$ & 9 & 9 \\
\multirow{3}{*}{ Sedang } & $\overline{\boldsymbol{X}}$ & 0,486 & 0,342 \\
& $\mathbf{S D}$ & 0,066 & 0,093 \\
& $\mathbf{N}$ & 18 & 19 \\
Rendah & $\overline{\boldsymbol{X}}$ & 0,301 & 0,212 \\
& $\mathbf{S D}$ & 0,095 & 0,140 \\
& $\mathbf{N}$ & 10 & 9 \\
& $\overline{\boldsymbol{X}}$ & 0,268 & 0,099 \\
& $\mathbf{S D}$ & 0,088 & 0,063 \\
\hline
\end{tabular}

Analisis Peningkatan Kemampuan Representasi Matematis Peserta didik Berdasarkan Faktor Pembelajaran dan KAM Peserta didik

Berdasarkan hasil pengujian normalitas dan homogenitas pada data kemampuan representasi matematis siswa menunjukkan bahwa kelompok data kemamuan representasi matematis berasal dari populasi yang berdistribusi normal dengan varians masing-masing pasangan kelompok data homogen, maka selanjutnya dilakukan analisis statistik menggunakan uji ANAVA dua jalur untuk melihat peningkatan kemampuan representasi matematis tersebut dan terdapat atau tidak terdapatnya interaksi antara pembelajaran dengan KAM peserta didik terhadap peningkatan kemampuan representasi matematis dengan hipotesis penelitian sebagai berikut:

Pada hipotesis pertama, hipotesis statistiknya adalah sebagai berikut:

$H_{0}: \mu_{1}=\mu_{2}$

$H_{0}: \mu_{1}>\mu_{2}$

Pada hipotesis ketiga, hipotesis statistiknya adalah sebagai berikut:

$H_{0}: \mu_{11}-\mu_{12}=\mu_{21}-\mu_{22}=\mu_{31}-\mu_{32}$

$H_{0}$ : paling tidak ada satu kelompok selisih rata-rata peningkatan kemampuan representasi matematis siswa yang berbeda dari yang lainnya berikut:

Adapun hasil analisis statistik menggunakan uji ANAVA dua jalur terangkum dalam tabel 7

Tabel 7. Hasil Uji ANAVA Dua Jalur N-Gain Kemampuan Representasi Matematis

\begin{tabular}{|c|c|c|c|c|c|}
\hline \multicolumn{6}{|c|}{$\begin{array}{c}\text { Tests of Between-Subjects Effects } \\
\text { Dependent Variable: Kem Representasi }\end{array}$} \\
\hline Source & $\begin{array}{l}\text { Type III } \\
\text { Sum of } \\
\text { Squares }\end{array}$ & Df & $\begin{array}{l}\text { Mean } \\
\text { Square }\end{array}$ & $\mathrm{F}$ & Sig. \\
\hline Corrected Model &, $808^{a}$ & 5 & , 162 & 15,385 & ,000 \\
\hline Intercept & 5,382 & 1 & 5,382 & 512,668 & ,000 \\
\hline KAM &, 520 & 2 & ,260 & 24,743 & ,000 \\
\hline Pendekatan_Pembelajaran & ,298 & 1 & ,298 & 28,377 & 000 \\
\hline $\begin{array}{l}\text { KAM } \\
\text { Pendekatan_Pembelajaran }\end{array}$ & ,023 & 2 & 012 & 1,098 & ,339 \\
\hline $\begin{array}{l}\text { Error } \\
\text { Total }\end{array}$ & $\begin{array}{r}, 714 \\
7,177\end{array}$ & $\begin{array}{l}68 \\
74\end{array}$ & 010 & & \\
\hline Corrected Total & 1,521 & 73 & & & \\
\hline
\end{tabular}

Beradasarkan tabel perhitungan uji ANAVA dua jalur di atas, dapat dilihat bahwa nilai $\mathrm{F}$ pada pembelajaran sebesar 28,377 dengan nilai signifikansi 0,000 yang lebih kecil dari taraf signifikansi 0,05 yang berarti $\mathrm{H}_{0}$ ditolak. Dengan kata lain, terdapat peningkatan kemampuan representasi matematis peserta didik yang diajar melalui pendekatan realistik berbasis budaya Melayu Langkat daripada peserta didik yang diajar melalui pembelajaran biasa. Sedangkan untuk faktor interaksi pendekatan pembelajaran dengan KAM diperoleh nilai $\mathrm{F}$ sebesar 1,098 dengan nilai signifikansi 0,339 yang lebih besar dari taraf signifikansi 0,05 yang berarti $\mathrm{H}_{0}$ diterima. Dengan kata lain, tidak terdapat interaksi antara pendekatan pembelajaran dengan KAM (tinggi, sedang, rendah) terhadap kemampuan representasi matematis peserta didik. Hal ini juga dapat diartikan, tidak terdapat pengaruh secara bersama yang diberikan oleh pendekatan pembelajaran dengan KAM terhadap kemampuan representasi matematis peserta didik. Peningkatan kemampuan representasi matematis peserta didik disebabkan oleh perbedaan pendekatan pembelajaran yang diterapkan bukan karena KAM yang dimiliki peserta didik. Sehingga dapat disimpulkan untuk menjawab hipotesis ketiga bahwa tidak terdapat interaksi antara pendekatan pembelajaran dengan KAM (tinggi, sedang, rendah) terhadap kemampuan representasi matematis peserta didik. 


\section{Peningkatan Minat Belajar Matematika Peserta didik Berdasarkan Faktor Pembelajaran dan KAM Peserta didik}

Gambaran peningkatan minat belajar matematika peserta didik pada masing-masing kelas eksperimen dan kelas kontrol dapat dilihat dari deskripsi $\mathrm{N}$-Gain yang terangkum dalam tabel 8 berikut:

Tabel 8. Deskripsi $N$-Gain Minat belajar Matematika Kedua Kelompok Pembelajaran untuk Kategori

KAM

\begin{tabular}{cccc}
\hline Kategori & Data & \multicolumn{2}{c}{ Pembelajaran } \\
\cline { 3 - 4 } KAM & Statistik & PRBBML & PB \\
Tinggi & $\mathbf{N}$ & 9 & 9 \\
& $\overline{\boldsymbol{X}}$ & 0,666 & 0,505 \\
\multirow{5}{*}{ Sedang } & SD & 0,127 & 0,154 \\
& $\mathbf{N}$ & 18 & 19 \\
& $\overline{\boldsymbol{X}}$ & 0,356 & 0,180 \\
Rendah & $\mathbf{S D}$ & 0,100 & 0,228 \\
& $\mathbf{N}$ & 10 & 9 \\
& $\overline{\boldsymbol{X}}$ & 0,119 & 0,051 \\
& $\mathbf{S D}$ & 0,052 & 0,056 \\
\hline
\end{tabular}

\section{Analisis Peningkatan Minat Belajar Matematika Peserta didik Berdasarkan Faktor Pembelajaran dan KAM Peserta didik}

Berdasarkan hasil pengujian normalitas dan homogenitas pada data minat belajar matematika peserta didik menunjukkan bahwa kempok data minat belajar matematika berasal dari populasi yang berdistribusi normal dengan varians masing-masing pasangan kelompok data homogen, maka selanjutmya dilakukan analisis statistik menggunakan uji ANAVA dua jalur untuk melihat peningkatan minat belajar matematika peserta didik dan terdapat atau tidaknya interaksi antara pembelajaran dengan KAM peserta didik terhadap minat belajar matematika dengan hipotesis penelitian sebagai berikut:

Pada hipotesis kedua, hipotesis statistiknya adalah sebagai berikut:

$H_{0}: \mu_{1}=\mu_{2}$

$H_{0}: \mu_{1}>\mu_{2}$

Pada hipotesis keempat, hipotesis statistiknya adalah sebagai berikut:

$H_{0}: \mu_{11}-\mu_{12}=\mu_{21}-\mu_{22}=\mu_{31}-\mu_{32}$

$H_{0}$ : paling tidak ada satu kelompok selisih rata-rata peningkatan kemampuan representasi matematis siswa yang berbeda dari yang lainnya berikut:

Adapun hasil analisis statistik menggunakan uji ANAVA dua jalur terangkum dalam tabel 9

Tabel 9. Hasil Uji ANAVA Dua Jalur N-Gain Minat Belajar Matematika

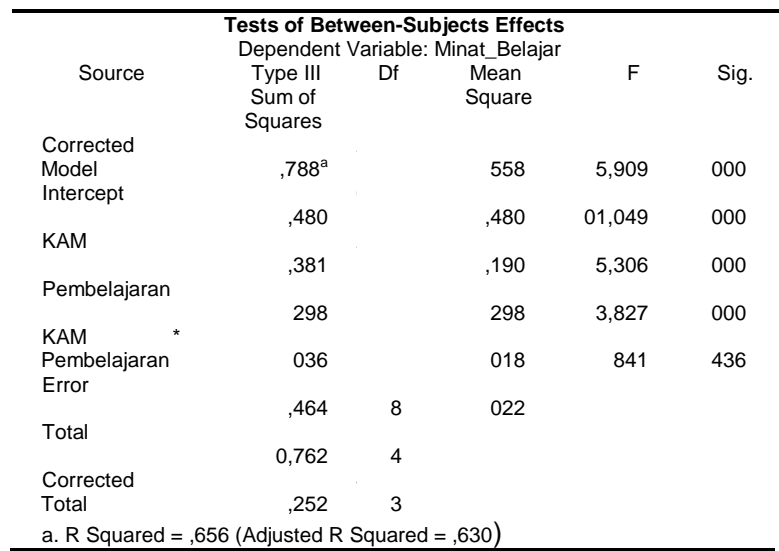

Beradasarkan tabel perhitungan uji ANAVA dua jalur di atas, dapat dilihat bahwa nilai $\mathrm{F}$ pada pembelajaran sebesar 13,827 dengan nilai signifikansi 0,000 yang lebih kecil dari taraf signifikansi 0,05 yang berarti $\mathrm{H}_{0}$ ditolak. Dengan kata lain, terdapat peningkatan minat belajar matematika peserta didik yang diajar melalui pendekatan realistik berbasis budaya Melayu Langkat daripada peserta didik yang diajar melalui pembelajaran biasa. Sedangkan untuk faktor interaksi pendekatan pembelajaran dengan KAM diperoleh nilai $F$ sebesar 0,841 dengan nilai signifikansi 0,436 yang lebih besar dari taraf signifikansi 0,05 yang berarti $\mathrm{H}_{0}$ diterima. Dengan kata lain, tidak terdapat interaksi antara pendekatan pembelajaran dengan KAM (tinggi, sedang, rendah) terhadap minat belajar matematika peserta didik. Hal 
ini juga dapat diartikan, tidak terdapat pengaruh secara bersama yang diberikan oleh pendekatan pembelajaran dengan KAM terhadap minat belajar matematika peserta didik. Peningkatan minat belajar matematika peserta didik disebabkan oleh perbedaan pendekatan pembelajaran yang diterapkan bukan karena KAM yang dimiliki peserta didik. Sehingga dapat disimpulkan untuk menjawab hipotesis keempat bahwa tidak terdapat interaksi antara pendekatan pembelajaran dengan KAM (tinggi, sedang, rendah) terhadap minat belajar matematika peserta didik.

\section{KESIMPULAN}

Berdasarkan pembahasan dan hasil penelitian yang telah dipaparkan sebelumya dapat disimpulkan berkaitan dengan peningkatan kemampuan representasi matematis dan minat belajar matematika peserta didik yang diajar melalui pendekatan realistik berbasis budaya Melayu Langkat bahwa: 1) peningkatan kemampuan representasi matematis peserta didik yang diajar melalui pendekatan realistik berbasis budaya Melayu Langkat lebih tinggi daripada peningkatan kemampuan representasi matematis peserta didik yang diajar melalui pembelajaran biasa;2) peningkatan minat belajar matematika peserta didik yang diajar melalui pendekatan realistik berbasis budaya Melayu Langkat lebih tinggi daripada peningkatan minat belajar matematika peserta didik yang diajar melalui pembelajaran biasa; 3) tidak terdapat interaksi antara pendekatan pembelajaran (pendekatan realistik berbasis budaya Melayu Langkat dan pembelajaran biasa) dengan kemampuan awal matematika (tinggi, sedang, dan rendah) terhadap peningkatan kemampuan representasi matematis peserta didik. Hal ini diartikan bahwa interaksi antara pendekatan pembelajaran (pendekatan realistik berbasis budaya Melayu Langkat dan pembelajaran biasa) dengan kemampuan awal matematika (tinggi, sedang, dan rendah) tidak memberikan pengaruh secara bersama-sama yang signifikan terhadap peningkatan kemampuan representasi matematis peserta didik. Perbedaan peningkatan kemampuan representasi matematis disebabkan oleh perbedaan pendekatan pembelajaran yang digunakan bukan karena kemampuan awal matematika peserta didik; 4) tidak terdapat interaksi antara pendekatan pembelajaran (pendekatan realistik berbasis budaya Melayu Langkat dan pembelajaran biasa) dengan kemampuan awal matematika (tinggi, sedang, dan rendah) terhadap peningkatan minat belajar matematika peserta didik. Hal ini diartikan bahwa interaksi antara pendekatan pembelajaran (pendekatan realistik berbasis budaya Melayu Langkat dan pembelajaran biasa) dengan kemampuan awal matematika (tinggi, sedang, dan rendah) tidak memberikan pengaruh secara bersamasama yang signifikan terhadap peningkatan minat belajar matematika peserta didik. Perbedaan peningkatan minat belajar matematika disebabkan oleh perbedaan pendekatan pembelajaran yang digunakan bukan karena kemampuan awal matematika peserta didik.

Berkaitan dengan pembahasan dan hasil penelitian yang telah diperoleh, diharapkan kepada peneliti selanjutnya untuk dapat menerapkan berbagai alternatif model atau pendekatan pembelajaran lainnya, khususnya dalam pembelajaran matematika untuk lebih dapat meningkatkan kemampuan representasi matematis dan minat belajar matematika peserta didik serta tidak menutup kemungkinan untuk meningkatkan kemampuan matematis dan sikap positif terhadap matematika lainnya.

\section{DAFTAR PUSTAKA}

Arifin, Z. (2011). Penelitian Pendidikan Metode dan Paradigma Baru. Bandung: PT. Remaja Rosdakarya.

Arifin, Z. (2014). Seni Budaya Melayu. Medan: Mitra Medan.

Aritonang, K. T. (2008). Minat dan Motivasi dalam Meningkatkan Hasil Belajar. Jurnal Pendidikan Penabur, 10(7).

Arsaythamby, V \& Zubainur, C M. (2014). How A Realistic Mathematics Educational Approach Affect Students' Activities In Primary Schools?. Procedia - Social and Behavioral Sciences, 159: 309 313.

Depdiknas. (2006). Standar Isi untuk Satuan Pendidikan Dasar dan Menengah. Jakarta: BSNP

NCTM. Executive Summary Principles and Standards for School Mathematics. Reston, VA: 20191 1502.

NCTM. (2000). Principles and Standards for School Mathematics. USA: Printed in the United States of America.

Ormrod, J.E. (2008). Psikologi Pendidikan Membantu Siswa Tunbuh dan Berkembang. Edisi Keenam, Penerbit Erlangga: Percetakan PT. Gelora Aksara Pratama.

Sabirin, M. (2014). Representasi dalam Pembelajaran Matematika. JPM IAIN Antasari Banjarmasin, $1(2), 33-34$.

Saragih, S. (2007). "Mengembangkan Kemampuan Berfikir Logis Dan Komunikasi Matematik Siswa Sekolah Menengah Pertama Melalui Pendekatan Metematika Realistik". Disertasi. Program Doktoral. Universitas Negeri Yokyakarta. Yogyakarta.

(2015). Aplikasi SPSS dalam Penelitian Pendidikan. Medan: Perdana Mulya Sarana. 
Siagian R.E.F. (2013). Pengaruh Minat dan Kebiasaan Belajar Siswa Terhadap Prestasi Belajar Matematika. Jurnal Formatif , 2(2), 122-131.

Sinaga, B. (2007). "Pengembangan Model PembelajaranMatematika Berdasarkan Masalah Berbasis Budaya Batak (PBM-B3)". Disertasi. Program Doktoral. Universitas Negeri Surabaya. Surabaya.

Wijaya, A. 2012. Pendidikan Matematika Realistik Suatu Alternatif Pendekatan Pembelajaran Matematika. Yogyakarta: Graha Ilmu.

Yudhanegara, dkk. (2014). Meningkatkan Kemampuan Representasi Beragam Matematis Siswa Melalui Pembelajaran Berbasis Masalah Terbuka. Jurnal Ilmiah Solusi, 1(3), 76-85. 